\title{
DIGOKSINO VARTOJIMAS VYRESNIO AMŽIAUS PACIENTŲ GRUPĖJE
}

\author{
Andrius Ališauskas, Laima Jankauskienė \\ Lietuvos sveikatos mokslu universiteto Medicinos akademijos Vidaus ligu klinika
}

Raktažodžiai: senyvas amžius, serumo digoksino koncentracija, inkstų funkcija, glomerulų filtracijos greitis, digoksino toksiškumas.

\begin{abstract}
Santrauka
Itvadas. Gydant progresuojantị širdies nepakankamumą su sumažèjusia kairiojo skilvelio išstūmimo frakcija šalia pagrindinių medikamentų grupių (AKFI/ARB, BAB, MRA) skiriamas ir digoksinas. Gydant vyresnio amžiaus pacientus svarbu atsižvelgti ị su amžiumi susijusius farmakokinetikos ir farmakodinamikos pokyčius: sumažejusị glomerulų filtracijos greitị, lytị, šalutines ligas. Vyresnio amžiaus pacientai blogiau toleruoja digoksino preparatus nei jaunesni. Jie turi padidejjusią digoksino toksiškumo riziką. Tyrimo medžiaga ir metodai. Atliktas retrospektyvinis tyrimas II lygio kardiologijos skyriuje. Tirti 65 metu ir vyresni pacientai, ambulatoriškai vartoję digoksiną. Tirtos sąsajos tarp serumo digoksino koncentracijos ir pacientų amžiaus, digoksino vartojimo schemos, lyties, kreatinino, kalio koncentracijos, glomerulų filtracijos greičio, sergamumo šalutinèmis ligomis, elektrokardiografinių pakitimų, diuretikų bei antiaritminių vaistų vartojimo.

Rezultatai. Vidutinè digoksino koncentracija serume 2,01 ng/ml (min. 0,40 ng/ml, maks. $-5,10 \mathrm{ng} / \mathrm{ml}$ ). Nustatyta, kad serumo digoksino koncentracija su amžiumi didèja $(r=0,261, p=0,000)$. Nustatyta sąsaja tarp inkstu funkcijos ir serumo digoksino koncentracijos. Kreatinino koncentracijos padidejimas lemia ir serumo digoksino koncentracijos padidejjimą $(\mathrm{r}=0,182, \mathrm{p}=0,009)$. Su amžiumi mažèja glomerulu filtracijos greitis, kuris susijęs su didèjančia serumo digoksino koncentracija $(r=-0,335, p=0,000)$. Nustatyta, kad tarp moterų digoksino koncentracija didesnè, nei tarp vyru $(\mathrm{p}<0,05)$. Didesnè digoksino paros dozé buvo susijusi su didesne digoksino koncentracija serume $(p<0,05)$. Antiaritminių vaistų ir diuretikų vartojimas taip pat buvo susijęs su didesne digoksino
\end{abstract}

koncentracija serume $(p<0,05)$. Didejjanti digoksino koncentracija serume lèmè elektrokardiografinius pokyčius: bradikardiją, skilvelines ekstrasistoles, atrioventrikulinę blokadą $(\mathrm{p}<0,05)$.

Išvados. Mūsų tyrimo duomenimis, didesnè serumo digoksino koncentracija buvo susijusi su vyresniu amžiumi, moteriška lytimi, didesne kreatinino koncentracija ir sumažejusiu glomerulų filtracijos greičiu, didesne paros digoksino doze, antiaritminių vaistų ir diuretikų vartojimu, elektrokardiografiniais pakitimais bei obstrukcinès plaučių ligos buvimu. Vyresniems pacientams rekomenduojama digoksino paros dozė yra 0,125 - 0,0625 mg. Serumo digoksino koncentracija $1 \mathrm{ng} / \mathrm{ml}$ yra pakankama. Tirtų pacientų vidutinè serumo digoksino koncentracija buvo 2,01 $\mathrm{ng} / \mathrm{ml}$, taigi viršijo rekomenduojamą. Lietuvoje nèra $0,125 \mathrm{mg}$ digoksino tablečių. Reikètų inicijuoti jų patekimą ị Lietuvos vaistų rinką.

\section{Ivadas}

Lètinio širdies nepakankamumo ( $\breve{S} N)$ gydymas žymiai pagerejo per pastaruosius 20 metų. Teigiamas renino - angiotenzino - aldosterono ir simpatinès nervų sistemos slopinimo efektas buvo įrodytas didelès apimties klinikiniais atsitiktiniu imčiu tyrimais. Medikamentinio gydymo optimizavimas angiotenziną konvertuojančio fermento inhibitoriais (AKFI)/ angiotenzino receptoriu blokatoriais (ARB), beta - adrenoreceptorių blokatoriais (BAB), mineralkortikoidu/aldosterono antagonistais (MRA) žymiai sumažino sergamumą ir mirštamumą dèl ŠN (1). Vis dèlto pacientams, sergantiems pažengusiu ŠN, liga progresuoja nepaisant optimalaus medikamentinio gydymo (2).

Širdį veikiantys glikozidai ( ŠVG) yra vieni iš seniausių medikamentų, kurie vis dar yra naudojami kardiologijoje. Pirmasis juos dar $1785 \mathrm{~m}$. aprašè britų gydytojas William'as Withering'as $(3,4)$. ŠVG širdies skersaruožiame raumenyje veikia teigiamai inotropiškai - didina kontrakciją, nedidindami širdies susitraukimų dažnio (ŠSD). Ląsteliniame lygmenyje digoksinas, slopindamas natrio - kalio pompą, 
didina intraląstelinio kalcio koncentraciją. Digoksinas turi ir neurohumoralinio slopinimo potencialą (5).

Gydant sumažèjusios kairiojo skilvelio išstūmimo frakcijos (IF) širdies nepakankamumą šalia pagrindinių medikamentų grupių (AKFI/ARB, BAB, MRA), skiriamas ir digoksinas (1). Dažniausiai digoksinas skiriamas ŠSD retinimui pacientams, kuriems yra prieširdžių virpejjimas (PV) ir ŠN (kartu su BAB) $(6,7)$. Taip pat digoksiną galima skirti ir sinusini ritmą (SR) turintiems pacientams, kurių IF $\leq 35$ proc. (1).

ŠVG yra plačiai naudojami vyresnio amžiaus pacientų, sergančių ŠN su supraventrikulinemmis tachiaritmijomis, tokiomis kaip PV, grupejje. Gydant vyresnio amžiaus pacientus svarbu atsižvelgti ị su amžiumi susijusius farmakokinetikos ir farmakodinamikos pokyčius: sumažejjusị glomerulų filtracijos greitị (GFG), lytį, šalutines ligas, dažnai pasitaikančią polipragmaziją $(4,8,9)$. Pastaraisiais dešimtmečiais keitèsi ir digoksino skyrimo indikacijos: anksčiau skirtas tik pacientams su PV, dabar ir vèl rekomenduojamas skirti pacientams su $\mathrm{SR}$, kai IF $\leq 35$ proc. $(1,5)$.

Mūsų tyrimo tikslas - nustatyti digoksino vartojimo ypatumus vyresnio amžiaus pacientų grupejje.

\section{Metodika ir duomenys}

$2014-2017$ m. Kauno klinikinès ligoninès kardiologijos skyriuje buvo atliktas retrospektyvinis tyrimas. Tyrime dalyvavo 204 pacientai

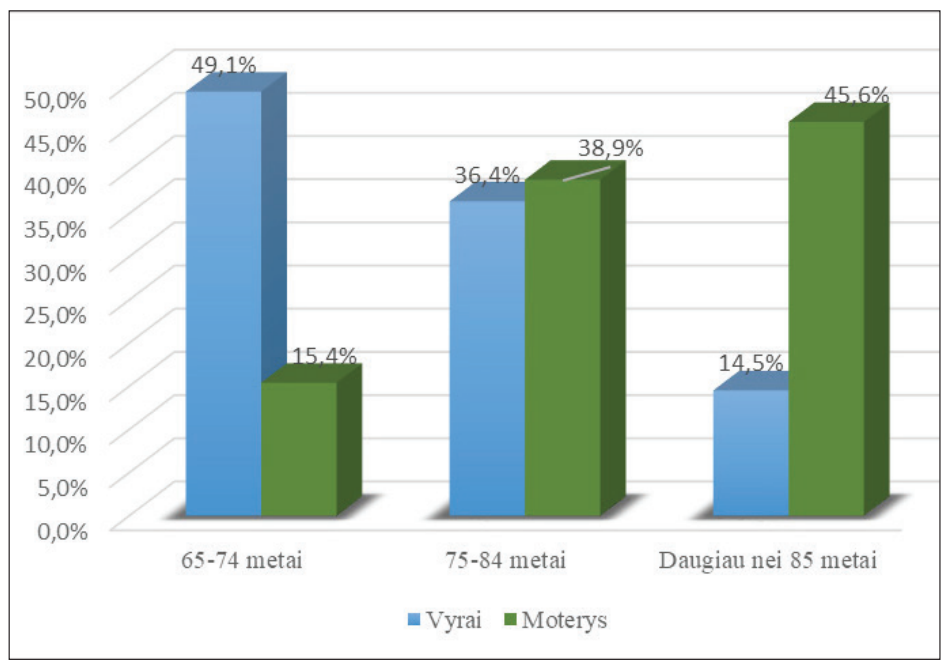

1 pav. Tiriamųjų pasiskirstymas pagal lytị ir amžių

\begin{tabular}{|l|c|c|c|c|c|c|}
\hline Amžiaus grupè & $\mathbf{N}$ & Vidurkis & SN & $\begin{array}{c}\text { Vid. } \\
\text { rangai }\end{array}$ & $\begin{array}{c}\chi^{\mathbf{2}} \\
\text { reikšmè }\end{array}$ & $\mathbf{p}$ \\
\hline $65-74$ metai & 50 & 1,05 & 0,978 & 81,31 & 10,422 & 0,005 \\
\cline { 1 - 5 } $75-85$ metai & 78 & 1,99 & 1,167 & 102,96 & & \\
\cline { 1 - 5 } $\begin{array}{l}\text { Vyresni nei } 85 \\
\text { metų }\end{array}$ & 76 & 2,32 & 1,356 & 115,97 & & \\
\hline
\end{tabular}

1 lentelè. Digoksino koncentracijos serume skirtumai skirtingose amžiaus grupèse
(65 m. ir vyresni, ambulatoriškai vartoję digoksiną, stacionarizuoti dèl ŠN paūmèjimo) - 55 (27 proc.) vyrai ir 149 (73 proc.) moterys. Buvo surinkti duomenys apie digoksino vartojimą (skirtingos skyrimo schemos), šalutines ligas, kitus vartojamus vaistus, užrašyta elektrokardiograma (EKG), atlikti laboratoriniai tyrimai: digoksino koncentracija serume (DKS), kreatinino ir kalio tyrimai. GFG apskaičiuotas naudojant Cockroft - Gault formulę (10).

Statistinè analizè. Tyrimo duomenų analizei atlikti naudota IBM SPSS for Windows 23.0. Tyrime pasirinktas statistinio reikšmingumo lygmuo $-\mathrm{p}<$ 0,05. Pagal Smirnovo-Kolmogorovo (SmirnovKolmagorov) kriterijų, visi skirstiniai statistiškai reikšmingai skyrèsi nuo normaliojo. Dèl to, nustatant sąsajas ir lyginant vidurkius, buvo naudojami Spirmeno (Spearman) koreliacijos koeficientas bei Kruskalio-Voliso (Kruskal-Wallis) neparametrinis kriterijus kelioms nepriklausomoms imtims palyginti. Tyrimo metu naudojama aprašomoji statistika ir gauti duomenys pateikti procentine išraiška arba kaip vidurkis \pm standartinis nuokrypis (SN).

\section{Rezultatai}

Tiriamujų amžius svyravo nuo 65 iki 99 metų, amžiaus vidurkis buvo $80,35 \pm 8,379 \mathrm{~m}$. Pagal amžių tiriamieji buvo suskirstyti ị tris grupes (1 pav.). Tiriamuju DKS vidutiniškai buvo $2,01 \mathrm{ng} / \mathrm{ml}$ (min $0,40 \mathrm{ng} / \mathrm{ml}$, maks $-5,10 \mathrm{ng} / \mathrm{ml}$ ). Rezultatai rodo, kad digoksino koncentracija didèja su amžiumi $(\mathrm{r}=0,261, \mathrm{p}=0,000)$. DKS statistiškai reikšmingai $(p<0,05)$ skiriasi skirtingose amžiaus grupèse $(1$ lentelè), didèjant amžiui didèja ir DKS.

Nustatyta, kad tarp moterų DKS yra aukštesnè, nei tarp vyrų, atitinkamai $2,22 \pm 1,287$ ir $1,42 \pm$ $0,815 \mathrm{ng} / \mathrm{ml}(\mathrm{p}<0,05)$.

Digoksiną pacientai vartojo pagal kelias skirtingas schemas. Kaip digoksinas buvo skiriamas pacientams galima matyti 2 paveiksle.

Dažniausiai (41,2 proc.) digoksinas buvo skirtas po $0,25 \mathrm{mg} / \mathrm{d}$. 5 dienas $/ \mathrm{sav}$. Palyginus DKS šiose skirtingų digoksino dozavimo schemų grupėse, nustatyta statistiškai reikšmingų skirtumų $(\mathrm{p}<0,05)$. Rezultatai pateikti 2 lentelèje.

Rezultatai rodo, kad mažiausia DKS yra naudojant dozavimo schemą po 0,125 mg kas dvi dienas, o didžiausia - naudojant schemą po $0,25 \mathrm{mg} / \mathrm{d} .7$ d./sav. Statistiškai reikšmingo skirtumo tarp pirmos ir antros digoksino skyrimo schemų nenustatyta.

Nustatyta, kad kilpiniai diuretikai statistiš- 
kai reikšmingai yra susiję su DKS ( $\mathrm{r}=0,179$, $\mathrm{p}=0,010$ ). Pacientų, kuriems neskirti kilpiniai diuretikai, DKS buvo 1,76 $\pm 1,189 \mathrm{ng} / \mathrm{ml}$, o grupeje, kuriems kilpiniai diuretikai skirti, DKS buvo $2,17 \pm 1,233 \mathrm{ng} / \mathrm{ml}(\mathrm{p}=0,011)$.

Nustatyta sąsaja tarp DKS ir inkstų funkcijos. Didejant kreatinino koncentracijai didejo ir digoksino koncentracija serume $(\mathrm{r}=0,182$, $\mathrm{p}=0,009)$. Su amžiumi dažnai mažèja GFG (9). Nustatyta, kad mažesnis GFG yra statistiškai reikšmingai susijęs su didejjančia DKS ( $\mathrm{r}=$ $-0,335, \mathrm{p}=0,000)$.

Vyresni pacientai dažniau serga šalutinėmis ligomis, viena iš dažnesnių šalutinių ligų yra lètinè obstrukcinè plaučių liga (LOPL). LOPL sąlygota lètinè hipoksemija didina jautrumą digoksinui. Mūsų atlikto tyrimo metu buvo nustatyta, kad sirgimas LOPL yra statistiškai reikšmingai susijęs su didesne digoksino koncentracija serume $(r=0,154, p=0,028)$.

Dél diuretikų vartojimo ir antrinio hiperaldosteronizmo dažnai nustatomas sumažèjęs kalio kiekis kraujyje, kuris didina intoksikacijos digoksinu riziką (4). Mūsų tyrimo metu nustatyta, kad kalio kiekis kraujyje nèra statistiškai reikšmingai susijęs su DKS ( $>00,05)$.

EKG analizè parodè, $\operatorname{kad} 21$ pacientui $(10,29$ proc.) buvo SR, 182 pacientams (89,21 proc.) - PV ir 1 pacientui $(0,49$ proc.) trečio laipsnio atrioventrikuliné (AV) blokada. Nustatyta, kad pakitimai EKG buvo susiję su DKS ( $\mathrm{r}=0,244$, $\mathrm{p}=0,001)$. Analizuojant EKG nustatyti sekantys digoksino intoksikacijos požymiai: bradikardija

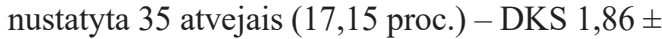
$1,107 \mathrm{ng} / \mathrm{ml}$, skilvelinès ekstrasistolès 40 atveju (19,6 proc.) - DKS 2,21 $\pm 1,207 \mathrm{ng} / \mathrm{ml}$, bradikardija su skilvelinėmis ekstrasistolëmis $13(6,37$ proc.) - DKS 3,34 $\pm 1,099 \mathrm{ng} / \mathrm{ml}, 3$ laipsnio AV blokada 1 pacientui (0,49 proc.) - DKS 2,6 ng/ $\mathrm{ml}(\mathrm{p}=0,001)$. Statistiškai reikšmingos sąsajos tarp ŠSD ir digoksino koncentracijos serume nenustatyta $(\mathrm{p}>0,05)$. Iš visų tirtų pacientų 15 atvejų (7,35 proc.) kartu su digoksinu skirti kalcio kanalų blokatoriai (KKB), jų DKS buvo 2,61 $\pm 0,796 \mathrm{ng} / \mathrm{ml}$, amjodaronas 6 pacientams $(2,94$ proc.) - DKS 2,64 $\pm 0,711 \mathrm{ng} / \mathrm{ml}$, amjodaronas ir KKB 5 (2,45 proc.) - DKS 3,54 $\pm 1,143 \mathrm{ng} /$ $\mathrm{ml}$, amjodaronas ir BAB 5 - iems (2,45 proc.) - DKS 2,96 $\pm 1,355 \mathrm{ng} / \mathrm{ml}$, neskirti jokie antiaritminiai vaistai 83 (40,68 proc.) - DKS $1,78 \pm$
$1,172 \mathrm{ng} / \mathrm{ml}$, BAB 90 (44,11 proc.) - DKS 1,76 $\pm 1,302 \mathrm{ng} / \mathrm{ml}(\mathrm{p}=0,009)$. Nustatyta statistiškai reikšminga digoksino koncentracijos serume ir antiaritminių vaistų sąsaja $(\mathrm{r}=0,226, \mathrm{p}=0,001)$.

\section{Rezultatu aptarimas}

Vyresnio amžiaus pacientams ŠVG dažnai skiriami gydyti ŠN, kai kartu yra PV (8). Nustatyta, kad digoksino toksiškumo rizika didèja su amžiumi $(5,11,12) .80$ procentų atvejų digoksino intoksikacija nustatoma vyresniems nei $60 \mathrm{~m}$. pacientams (8). Dauguma tirtų pacientų vartojo digoksiną po $0,25 \mathrm{mg} 5$ dienas per sav. (n $84-41,18$ proc.), po $0,25 \mathrm{mg}$ kas 2 - ą d. (n $45-22,06$ proc.) arba po 0,25 mg kasdien (n $51-25$ proc.). Šiuo metu Lietuvos rinkoje nèra digoksino tablečių po $0,125 \mathrm{mg}$, nors tam, kad būtų sumažinta digoksino paros doze, yra ir kitų vartojimo schemų, tačiau ypač vyresnio amžiaus pacientams jos gali būti sunkiai isimenamos, dèl to didejja intoksikacijos rizika.

Vyresnio amžiaus pacientų grupeje dèl ịvairių digoksino toksiškumą didinančių faktorių terapinè ir toksinè SDK dažnai persidengia. Vyresni pacientai yra jautresni digoksinui, nei jaunesni $(3,4,12)$. Optimali SDK galètų būti nuo $0,5 \mathrm{iki} 0,8 \mathrm{ng} / \mathrm{ml}$ (9). Mūsų tiriamujų vidutinè DKS buvo $2,01 \mathrm{ng} / \mathrm{ml}$, kas gerokai viršijo rekomenduojamas ribas. Digoksino skilimo pusperiodis svyruoja nuo 36 iki 70 val. (8). Pagal mūsų tyrimą SDK svyravo plačiose ribose - nuo 0,40 iki $5,10 \mathrm{ng} / \mathrm{ml}$. Tai tik dar kartą patvirtina, kad SDK priklauso nuo daugelio faktorių (amžiaus, lyties, inkstų funkcijos, šalutinių ligų ir vartojamų medikamentų) ir jų kombinacijų. Nustatyta, kad SDK didèjo su amžiumi $(r=0,261, p<0,05)$.

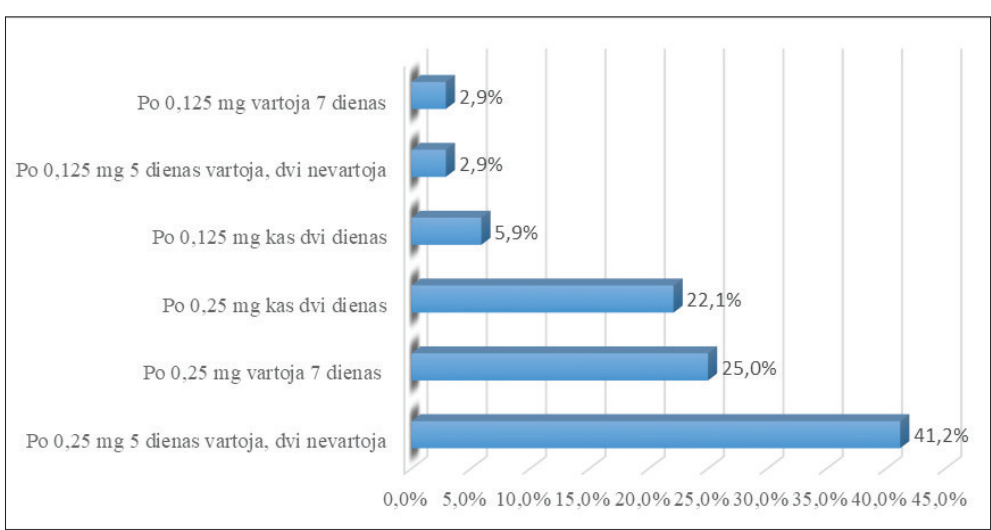

2 pav. Tiriamųų pasiskirstymas pagal digoksino peroralinị vartojimą

2 lentelè. Digoksino koncentracijos serume skirtumai skirtingose dozavimo schemų grupèse

\begin{tabular}{|c|c|c|c|c|c|c|}
\hline $\begin{array}{l}\text { Digoksino dozavimo } \\
\text { schema }\end{array}$ & $\mathbf{N}$ & Vidurkis & SN & Vid. rangai & $\begin{array}{c}\chi^{2} \\
\text { reikšmè }\end{array}$ & $\mathbf{p}$ \\
\hline 1. $0,25 \mathrm{mg}$ kas $2 \mathrm{~d}$. & 45 & 1,97 & 1,172 & 102,07 & \multirow[t]{6}{*}{17,563} & \multirow[t]{6}{*}{0,004} \\
\hline 2. $0,25 \mathrm{mg} 5 \mathrm{~d} . / \mathrm{sav}$. & 84 & 1,95 & 1,302 & 97,71 & & \\
\hline 3. $0,125 \mathrm{mg}$ kas $2 \mathrm{~d}$. & 12 & 1,15 & 0,796 & 59,00 & & \\
\hline 4. $0,125 \mathrm{mg} 5 \mathrm{~d} . / \mathrm{sav}$ & 6 & 1,32 & 0,711 & 71,42 & & \\
\hline 5. $0,25 \mathrm{mg} 7 \mathrm{~d} . / \mathrm{sav}$. & 51 & 2,44 & 1,143 & 126,45 & & \\
\hline 6. $0,125 \mathrm{mg} 7 \mathrm{~d} . / \mathrm{sav}$. & 6 & 1,77 & 1,355 & 87,25 & & \\
\hline
\end{tabular}


Digitalio tyrimo grupès (DIG) klinikinè studija parode, kad 65 metų ir vyresnių pacientų amžiaus grupejje net ir maža SDK $(0,5-0,9 \mathrm{ng} / \mathrm{ml})$ lemia sumažėjusią mirštamumo riziką, todèl yra pakankama (13). Tarp vyresnių pacientų, sergančių ŠN, dažnas ir PV. Šiai grupei pakankama SDK yra apie $1 \mathrm{ng} / \mathrm{ml}$ (14). Šiems pacientams rekomenduojama digoksino paros dozè yra $0,125 \mathrm{mg}(3,12)$. Gydymas turetu būti pradètas tokia pačia doze. SDK tyrimas nèra privalomas kasdienėje praktikoje (3). Vyresnèms nei $75 \mathrm{~m}$. moterims, vyresniems pacientams, sergantiems lètine inkstų liga (LIL), kuriems kartojasi plaučių edemos ir/arba gydomiems didelëmis diuretikų dozėmis turètų būti skiriama net ir maženè digoksino doze - 0,125 mg kas antrą dieną (3).

Digoksino poveikis priklauso ir nuo lyties. Moteru grupejje jis didina mirštamumą (15). Mūsų tyrimo metu nustatyta, kad tarp moterų DKS buvo aukštesnis, nei tarp vyrų, atitinkamai 2,22 $\pm 1,287$ ir $1,42 \pm 0,815 \mathrm{ng} / \mathrm{ml}(\mathrm{p}<0,05)$. Retrospektyvinė DIG klinikinès studijos duomenų analizė parode, kad tarp moterų teigiamas digoksino poveikis pasireiškia tada, kai SDK yra 0,5 - 0,9 $\mathrm{ng} / \mathrm{ml}$ ribose, tuo tarpu $\mathrm{SDK}>1,2 \mathrm{ng} / \mathrm{ml}$ jau didina mirštamumą (16).

Dažniausiai intoksikaciją digoksinu sąlygoja diuretikų vartojimo ar antrinio hiperaldosteronizmo sąlygota hipokalemija, vyresnis amžius, miokardo išemija ar infarktas, hipotiroze, hipokalcemija, LIL. Digoksino toksiškumą didina ir vaistai: chinidinas, verapamilis, diltiazemas, eritromicinas, klaritromicinas, kaptoprilis, ibuprofenas, anticholinerginiai vaistai, amjodaronas (4). Vyresniame amžiuje pacientai paprastai gydomi kelių grupių vaistais, todèl yra sunkiau išvengti jų sąveikos (8). Mažai judančių pacientų grupejje digoksino monoterapija galètų būti pakankama $(7,17)$. Tačiau nemaža dalis vyresnių pacientų gyvena pakankamai aktyvų gyvenimą, todėl tarp aktyviai judančių digoksino monoterapija negali užtikrinti pakankamos ŠSD kontrolès. Tokiu atveju digoksinas vartojamas kartu su BAB ar KKB (verapamiliu, diltiazemu) $(6,17)$. Digoksino ir BAB kombinacija yra labiau pageidaujama, efektyvesnè ir saugesnè (1, 7). Tyrimo metu nenustatyta statistiškai reikšmingos kalio kiekio kraujyje ir DKS sąsajos ( $p>0,05$ ), tačiau kilpinių diuretiku vartojimas buvo susijęs su didesne SDK ( $r=0,179$, $\mathrm{p}=0,010$ ). Iš mūsų tirtų pacientų grupés 7,35 proc. kartu su digoksinu skirti $\mathrm{KKB}$, amjodaronas 2,94 proc., amjodaronas ir KKB 2,45 proc., amjodaronas ir BAB 2,45 proc., tik BAB 44,11 proc. o 40,68 proc. neskirti jokie antiaritminiai vaistai. Skiriant daugiau antiaritminių vaistų (amjodaroną, KKB ir jų derinį) didejjo ir SDK $(\mathrm{r}=0,226, \mathrm{p}=0,001)$.

Vyresniems pacientams dažniau pasitaiko elektrolitų disbalansas ir blogesnè inkstų funkcija. Nors kreatinino koncentracija serume gali būti normali, tačiau GFG, ypač mažesnès masès pacientams, gali būti sumažèjęs (17). Mūsų tyrimo metu nustatyta, kad DKS didejjo esant didesnei kreatinino koncentracijai serume ir mažesniam GFG.

Pacientams, kurie serga LOPL, digoksinas gali sąlygoti plaučių arterijų vazokonstrikciją. Dèl hipoksijos ir acidozès šie pacientai patenka ị didelès digoksino intoksikacijos rizikos grupę. Todèl reikètų vengti skirti digoksiną pacientams, kurie serga LOPL sąlygotu dešiniojo skilvelio nepakankamumu (12). Mūsų tyrimo metu nustatyta, kad LOPL sąlygojo didesnę SDK.

Intoksikacija digoksinu pasireiškia ịvairiais nusiskundimais ir simptomais - pykinimu, galvos skausmu, vėmimu, viduriavimu, bendru silpnumu, spalvinio regejjimo pakitimais. Intoksikacija digoksinu sąlygoja ir ịvairias aritmijas - sinusinę bradikardiją, sinusines pauzes, AV blokadas, skilvelines ekstrasistoles, skilvelinès tachiaritmijas $(4,7,8$, 11, 18). Šių aritmijų pasireiškimo riziką taip pat didina ir vyresnis amžius, hipokalemija, LOPL, amiloidozè, LIL (11). Mūsų tyrimo metu sąsajos tarp ŠSD ir DKS nenustatyta. Iš visų tirtų pacientų bradikardija nustatyta 17,15 proc., skilvelinès ekstrasistolès 19,6 proc., bradikardija su skilvelinèmis ekstrasistolèmis 6,37 proc., 3 laipsnio AV blokada 0,49 proc.

Mūsų tyrimas parodè, jei pacientams skiriamos didesnès nei rekomenduojamos digoksino dozès, didejja DKS ir digoksino toksiškumo rizika. Dalinai tą būtų galima paaiškinti tuo, kad Lietuvos rinkoje nèra mažesnès digoksino dozuotès tablečių $(0,125 \mathrm{mg})$ ir nusistovejjusiomis digoksino skyrimo tradicijomis. Tyrimo metu nustatyta, kad skiriant digoksiną po $0,125 \mathrm{mg}$ kas antrą dieną vidutinė DKS buvo $1,15 \pm$ $0,796 \mathrm{ng} / \mathrm{ml}$, o po $0,125 \mathrm{mg}$ penkias dienas per sav. $1,32 \pm$ $0,711 \mathrm{ng} / \mathrm{ml}$.

\section{Išvados}

1. Tyrimo metu nustatyta, kad didesnè DSK buvo susijusi su vyresniu amžiumi, moteriškaja lytimi, didesne kreatinino koncentracija ir mažesniu GFG, diuretikų ir antiaritminių vaistų vartojimu, LOPL.

2. Vyresniems pacientams rekomenduojama digoksino paros dozė yra $0,0625-0,125 \mathrm{mg}$. $1 \mathrm{ng} / \mathrm{ml}$ digoksino koncentracija yra pakankama. Tirtų pacientų vidutinė DKS daugiau nei du kartus viršijo pageidaujamą, t. y. 2,01 ng/ml.

3. Lietuvos rinkoje nèra $0,125 \mathrm{mg}$ digoksino tabletinès formos, todèl reikètų inicijuoti jų patekimą ị mūsų rinką.

\section{Literatūra}

1. 2016 ESC Guidelines for the diagnosis and treatment of acute and chronic heart failure. European Heart Journal (2016); 37:2129-2200.

https://doi.org/10.1093/eurheartj/ehw128

2. McDonagh TA. Challenges in advanced chronic heart failure: drug therapy. Future cardiology 2008; 4(5):517-525.

https://doi.org/10.2217/14796678.4.5.517 
3. Ahmed A. An update on the role of digoxin in older adults with chronic heart failure. Geriatrics and Aging 2008;11(1):37-41.

4. Patel V, James PA. Digitalis toxicity. Internetinè prieiga adresu: http://emedicine.medscape.com/article/154336-overview; atnaujinta 2017-01-04; žiūrèta 2018-06-11.

5. Haji SA, Movahed A. Update on digoxin therapy in congestive heart failure. American Family Physician 2000;62(2):401-409.

6. Khad AU. et al. Carvedilol alone or in combination with digoxin for the management of atrial fibrillation in patients with heart failure? Journal of the American College of Cardiology 2003;42:1944-1951.

https://doi.org/10.1016/j.jacc.2003.07.020

7. Jones C. et al. Management of atrial fibrillation: summary of updated NICE guidance. British Journal of Cardiology 2014;348:g3655.

https://doi.org/10.1136/bmj.g3655

8. Roever C. et al. Comparing the toxicity of digoxin and digitoxin in ageriatric population: should an old drug be rediscovered? Southern Medical Journal 2000;93(2);199-202. https://doi.org/10.1097/00007611-200093020-00009

9. Rathore SS. et al. Association of serum digoxin concentration and outcomes in patients with heart failure. JAMA 2003;289(7):871-878.

https://doi.org/10.1001/jama.289.7.871

10. Ferreira. et al. Renal function estimation and Cockcroft-Gault formulas for predicting cardiovascular mortality in populationbased, cardiovascular risk, heart failure and post-myocardial infarction cohorts: The Heart 'OMics' in AGEing (HOMAGE) and the high-risk myocardial infarction database initiatives. BMC Medicine 2016;14:181.

https://doi.org/10.1186/s12916-016-0731-2

11. Brownwald E. et al. Heart Disease 6th edition. WB Saunders company 2001;573-579, 739.

12. Aronow WS. Treatment of heart failure in older persons. Congestive Heart Failure 2003:9(3).

https://doi.org/10.1111/j.1527-5299.2003.01388.x

13. The Digitalis Investigation Group. The effect of digoxin on mortality and morbidity in patients with heart failure. New England Journal of Medicine 1997;336:525-533.

https://doi.org/10.1056/NEJM199702203360801

14. Weir RAP. et al. Heart failure in older patients. British Journal of Cardiology 2006;13:257-266.

15. Rathore SS. et al. Sex - based differences in the effect of digoxin for the treatment of heart failure. New England Journal of Medicine 2002;347(18):1403-1410.

https://doi.org/10.1056/NEJMoa021266

16. Adams KF Jr. et al. Relationship of serum digoxin concentration to mortality and morbidity in women in the digitalis investigation group trial: retrospective analysis. Journal of the American College of Cardiology 2005;46(3):497-504. https://doi.org/10.1016/j.jacc.2005.02.091

17. Falk RH. Ventricular rate. Control in the elderly: is digoxin enough? The American Journal of Geriatric Cardiology 2002;11(6):353-356.

https://doi.org/10.1111/j.1076-7460.2002.00067.x
18. Forman DE, Rich MW. Heart failure in the eldery. Congestive Heart Failure 2003;9(6):311-323.

https://doi.org/10.1111/j.1527-5299.2003.00798.x

\section{USE OF DIGOXIN IN THE ELDERLY}

\section{A.Ališauskas, L.Jankauskienė}

Key words: eldery, serum digoxin concentration, renal function, glomerular filtration rate, digoxin toxicity.

Summary

Background. Digoxin may be used in patients with heart failure with reduced ejection fraction and AF to slow rapid ventricular rate in addition to, or prior beta blocker. Also digoxin may be used in patients with heart failure with reduced ejection fraction $(\leq 35 \%)$ and sinus rhythm. In the management of older patients it is important to take into account age related changes of pharmacokinetics and pharmacodynamics, decreased glomerular filtration rate, sex and concomitant diseases. Older individuals have lower tolerance of digitalis than younger. They have increased risk of digitalis toxicity.

Materials and methods. Inclusion criteria were age $\geq 65$ years' patients, who used digoxin in outpatient settings and were hospitalized due to heart failure flare-up. Relation of serum digoxin concentration with age, sex, presence of concomitant diseases, creatinine and potassium concentrations, digoxin use pattern, electrocardiographical changes, diuretics and antiarrhythmics usage, and glomerular filtration rate was assessed.

Results. The mean serum digoxin concentration of study subjects was $2,01 \mathrm{ng} / \mathrm{mL}$ ( $\min 0.40 \mathrm{ng} / \mathrm{mL}$, $\max -5.10 \mathrm{ng} / \mathrm{mL}$ ). According to our data serum digoxin concentration increased with age $(\mathrm{r}=0.261, \mathrm{p}=0.000)$. Females had higher serum digoxin concentration as compared to males $(\mathrm{p}<0,05)$. The relation between renal function and serum digoxin concentration was assessed. Increase in creatinine concentration resulted in increase in serum digoxin concentration $(r=0.182, p=0.009)$. Age is associated with decline in glomerular filtration rate. Decline in the glomerular filtration rate was associated with increased serum digoxin concentration $(r=-0.335$, $\mathrm{p}=0.000$ ). Presence of chronic obstructive pulmonary disease was associated with higher serum digoxin concentration. Usage of antiarrhythmic agents and diuretics is associated with higher serum digoxin concentration $(\mathrm{p}<0,05)$. Electrocardiographical changes such as ventricular premature complexes, bradycardia, complete heart block was associated with higher serum digoxin concentration $(\mathrm{p}<0.05)$. In patients with lower daily dose of digoxin serum digoxin concentration was lower $(\mathrm{p}<0.05)$

Conclusions. In our study higher serum digoxin concentration was associated with older age, female gender, diuretic and antiarythmic drug usage, higher daily dose of digoxin, electrocardiographical changes (bradycardia, premature ventricular compexes, complete heart block), increased creatinine level and lower glomerular filtration rate, and presence of chronic obstructive pulmonary disease. For older patients recommended digoxin daily dose is $0.125-0.0625 \mathrm{mg}$. Serum digoxin concentration of $1 \mathrm{ng} / \mathrm{mL}$ is sufficient. The mean serum digoxin concentration of study subjects was $2.01 \mathrm{ng} / \mathrm{mL}$, thus exceeded recommended by guidelines. In Lithuania $0.125 \mathrm{mg}$ digoxin tablets are not available. Initiatives should be taken to have it in Lithuanian drug market.

Correspondence to: and.alisauskas@gmail.com

Gauta 2018-07-04 